\title{
WW Domain Binding Protein 1-Like
}

National Cancer Institute

\section{Source}

National Cancer Institute. WW Domain Binding Protein 1-Like. NCI Thesaurus. Code C113284.

WW domain binding protein 1-like (342 aa, $38 \mathrm{kDa}$ ) is encoded by the human WBP1L gene. This protein may be involved in binding to heme. 